

\section{Türkiye'de Politik Konjonktürel Dalgalanmalar: 1950-2003 Dönemi}

\section{Giris}

Politik konjonktürel dalgalanmalar teorisi hükümetin ekonomiyi kendi çıkarları doğrultusunda manipüle edip, etmediğini araştırır. Bu konu literatürde dört farklı yaklaşımla ele alınmaktadır. Bunlar fırsatçı politik konjonktürel dalgalanmalar, partizan konjonktürel dalgalanmalar, rasyonel fırsatçı konjonktürel dalgalanmalar ve rasyonel partizan konjonktürel dalgalanmalardır. Bu çalışmada, fırsatçı politik konjonktürel dalgalanmalar ele alınıp, Türkiye'de bu tür dalgalanmalann var olup, olmadığı incelenecektir. Türkiye için en uygun model fırsatçı konjonktürel dalgalanmalar modelidir. Rasyonel konjonktürel dalgalanmalar modeli, fırsatçı konjonktürel dalgalanmalar modelinden çok az da olsa farklıdır. Rasyonel modelde seçmenler "rasyonel"dir, yani makro ekonomi ile ilgili elde edebildikleri tüm bilgileri beklentilerine dahil edebilmekteler ve bugünün ekonomi politikalannın gelecekteki sonuçlarını anlayabilmektedirler. $\mathrm{Bu}$ durumda rasyonel modelde iktidar partileri fırsatçı konjonktürel dalgalanmalar yaratacak politikaları iktidarlanının sadece küçük bir bölümünde takip etmektedirler (Bu dönem seçimlerden hemen önceki dönemdir). Bu teorik farklılıktan dolayı rasyonel konjonktürel dalgalanmaların tahminleri, fırsatçı - konjonktürel dalgalanmalara göre kısa dönemli ve bir defaya mahsus döngülerden ibarettir. $\mathrm{Bu}$ nedenle rasyonel konjonktürel dalgalanmalar seçimlerden önceki kısa bir dönemi araştırmak için uygun olmakla beraber tüm seçim dönemini araştırmak için uygun bir model değildir. Biz bu çalışmada Türkiye'de tüm seçim döneminde fırsatçı politik dalgalanmaların var olup, olmadığını araştırmak istediğimizden, rasyonel politik konjonktürel dalgalanmalar amacımız açısından uygun olmamaktadır.

Türkiye için firsatçı politik konjonktürel dalgalanmalar modeli, partizan teori ve rasyonel partizan konjonktürel dalgalanmalar teorisinden daha uygundur. Partizan ve rasyonel partizan modellerde, politik partilerin birbirlerinden farklı ekonomik ideolojileri vardır. Sol partiler daha çok işsizliği 
azaltmaya yönelmekle beraber, sağ partiler daha çok enflasyonu düşürmeye odaklanmışlardır. Fakat bu modeller Türkiye şartlan ile pek bağdaşmamaktadır. Genelde partizan modeller $\mathrm{ABD}$, İngiltere gibi iki parti sisteminin var olduğu ülkelerde görülmektedir. Türkiye'de ise, partilerin ekonomi politikaların ideolojik olarak kesin sınırlarla ayırmak pek mümkün değildir. Yani Türkiye'de bazen sağ partilerin hedefi de işsizliği düşürmek olabilmektedir. Yine Türkiye'de politik konjonktürel dalgalanmalarla ilgili çok az olan çalışmalardan Akçoraoğlu ve Yurdakul (2004) ve Sayan ve Breumer (1997) çalışmalannda Türkiye'de partizan ve rasyonel partizan konjonktürel dalgalanmaların varlığını tespit edememişlerdir.

Türkiye'de politik konjonktürel dalgalanmaların var olup olmadığının incelenmesi bir çok açıdan önemlidir. Her şeyden önce Türkiye'nin son zamanlarda yaşamış olduğu ekonomik krizlerin nedenleri arasında politik konjonktürel dalgalanmaların payının olup olmadığının belirlenmesidir. Eğer Türkiye'de politik konjonktürel dalgalanmalar var ise, ekonomik krizlerin önlenmesi açısından bir çözüm yolư araştırılırken bu durumda göz önünde bulundurulmalıdır. Ayrıca, gelişmekte olan ülkelerle ilgili politik konjontürel dalgalanmalar teorisi çok az çalışılmıştır. Bu nedenle bu çalışma bu açığı kapatmayı hedeflemektedir. Gelişmekte olan ülkelerle ilgili çalışmaların zenginleştirilmesi dışında, fırsatçı konjonktürel dalgalanmalann bu tür ülkeler açısından da geçerli olup olmadığının tespit edilmesi de diğer önemli bir husustur.

Bu konu ile ilgili bir temel araştırma sorumuz ve bunu destekleyen alt araştırma sorularımız vardır.

Türkiye'de Politik konjonktürel dalgalanmalar var midır?

a- Eğer Türkiye'de politik konjonktürel dalgalanmalar var ise, bunlarn en belirgin karakteristikleri nelerdir?

b- Eğer politik konjonktürel dalgalanmalar var ise, kullanılan en önemli ekonomik araç değişkenleri nelerdir? Türkiye'nin kullandığı özel bir değişken var mıdır?

c- Türkiye'de örneğin ekonomik araç değişkenleri ile ekonomik çıktı değişkenleri arasında herhangi bir farklılık var mıdır? Ekonomik çıktılar açısından politik konjonktürel dalgalanmalar olmasa bile ekonomik araç değişkenlerinin durumu da kontrol edilmelidir.

Bu araştırma sorulanını test etmek amacıyla, Türkiye'de 1950-2003 dönemi ele alınmıştır. Bu dönemler itibariyle Türkiye'de politik konjonktürel dalgalanmaların var olup, olmadığını en küçük kareler yöntemine (OLS) göre test edilecektir. Bu analiz politika çıktılarına ve politika araçlarına göre yapılacaktır. Politika çıktıları olarak enflasyon ve büyüme kullanılacaktır. 
Güvenilir işsizlik verisi, diğer bir çok gelişmekte olan ülkelerde olduğu gibi Türkiye'de de elde edilmesi güç bir veridir. İşsizlik yerine kullanılacak başka bir veri olmadığı içinde şimdiye kadar Türkiye ile ilgili yapılan çalışmalarda kullanılamamıştır. İşsizlik verilerini toplamak lojistik olarak oldukça güçtür. Politika araçlarına göre yapılan analizde ise, para arzı, kamu harcamalan, bütçe açıkları ve vergiler kullanılacaktır.

Çalışmanın giriş bölümünü takip eden bölümde, politik konjonktürel dalgalanma modellerinden fırsatçı modellerin varsayımlan kısaca gözden geçirildikten sonra, Türkiye'nin 1946 yılı seçimleriyle başlayan çok partili demokratik hayatın kısa bir özeti verilecektir. Bunu takip eden bölümde Türkiye'de çok partili hayata geçiş ile politik konjonktürel dalgalanmaların var olup, olmadığı politika çıktılarına ve politika araçlanna göre test edilecektir.

\section{POLITIK KONJONKTUREL DALGALANMALAR TEORISI}

Geniş anlamda politik konjonktür dalgalanmalan bazı ekonomik ve politik avantajlar elde etmek amacıyla ekonomiyi hile ile yöneten seçime aday politikacıların ve iktidardaki politikacının seçim döneminde ekonomiye pompaladığ fonlarla artan, kişisel gelir ve ekonomik teşviklerle (genişletici politikalar), seçim beklentilerine uyarlanmıs pek çok politikanın (yeniden seçim baskısı) periyodik seçim rekabeti sonucu makro ekonomik değişkenler üzerinde kısa ve uzun dönemde, devresel bir etki yapması olarak tanımlanmaktadır (Onur, 2002:86; Onur, 2003:2). Politik konjonktürel dalgalanmalar teorisinin temel hareket noktası, ekonomik döngüler ile siyasi döngüler arasında bir ilişkinin varlığıdır. Bu ilişki temelde, ekonomi politikalarının genel seçimler ile iktidara gelmis siyasi otoriteler tarafından belirlenmesinden kaynaklanmaktadır. Politik konjonktürel dalgalanmalar teorilerinin geliştirilmesi ile daha önce gözlem ve yorumlamalara dayanan araştırmaların yerine, artık hükümetlerin seçimleri de dikkate alarak ekonomi politikalannı uyguladıklan varsayımına dayanan formel modeller geliştirilmiştir (Telatar, 2000:133). Politik konjonktürel dalgalanmalar teorisi literatürde dört farklı yaklaşımla incelenmektedir. Bunlar fırsatçı politik konjonktürel dalgalanmalar, partizan konjonktürel dalgalanmalar, rasyonel firsatçı konjonktürel dalgalanmalar ve rasyonel partizan konjonktürel dalgalanmalardır. Fırsatçı politik konjonktürel dalgalanmalar, iktidar partilerinin seçim kazanmak amacıyla ekonomiyi manipüle etme çabaları sonucunda oluşan devresel dalgalanmalan ifade eder (Young Heun, 2002:13-14).

Partizan konjonktürel dalgalanmalarda ise, partilerin ideolojileri çerçevesinde belirlenen politikalan uygulayarak seçimleri kazanmak amacı ile ekonomiyi manipüle etmeleri söz konusudur. Daha sonra rasyonel beklentiler kuramının 
gelişmesiyle bu iki modele, rasyonel fırsatçı konjonktürel dalgalanmalar ve rasyonel partizan konjonktürel dalgalanmalar modelleri eklenmiştir. Yani, politik konjonktürel dalgalanmalar, politikacılann ekonomi üzerindeki her türlü etkilerini kapsar (Alcoe, 2001:9).

\subsection{Fırsatçı Politik Konjonktürel Dalgalanmalar}

Hemen hemen herkesin kabul edeceği gibi, politikacılar iş başında olmayı severler. Hatta bir çok siyaset kuramına göre de seçmenler uygulanan politikalara önem verirken, politikacılar sadece seçimleri kazanmayı düşünürler ve bu nedenle de politikalarını seçmenleri memnun edecek doğrultuda seçerler. Bu tür davranışlan "fırsatçı"(opportunistic) olarak değerlendirebiliriz. Politikaclların iş başında kalabilmek için para ve maliye politikalannı seçerken ne kadar fırsatçı olduklarını gösteren makro ekonomik politikalar mevcuttur. Bunlardan en popüler olanı; geleneksel fırsatçı politik konjonktür modeldir. Bu model Nordhaus (1975:169-190) tarafından geliştirilmiştir. Nordhaus' un ortaya attığı bu model rasyonel olmayan bir modeldir ve Keynesyen makro ekonomik teori ile ortalama seçmen teorisine dayanmaktadır (Suzuki, 1992:989). Bu modelde fırsatçı politikacılar Phillips eğrisini istismar ederek, kendi çıkarlan doğrultusunda kullanırlar. Seçmenler geçmiş olaylan çok çabuk unuttuklarından, politika belirleyicilerin niyetlerinin farkında olmadıklarından ve ekonominin nasıl işlediğini bilemediklerinden, özellikle enflasyon ve işsizlik arasındaki değişimi hesaba katmadıklanndan, politikacılar tarafından kullamlabilmektedirler. Bu geleneksel politik konjonktür modeline göre, iktidardaki hükümet seçimlerden hemen önce yapay olarak ekonomiyi harekete geçirir ve ekonomiyi genişletir, seçimlerden sonra enflasyon sonuçlannı elimine etme yoluna gider. Bu davranışları seçmenler tarafından ödüllendirilir. Çünkü seçimler ekonominin geçiçi olarak iyileştiği dönemlerde yapılır ve bu fırsatçı davranışların doğasını seçmenler anlayamadıklarından aldatılmalanı söz konusudur. Seçmenler geçmis deneyimlerinden ders almazlar ve bir önceki dönem seçim sonrası ekonomik durgunluğu yaklaşan seçimler zamanı unuturlar (Alesina, Roubini / Cohen, 1997:16).

\subsubsection{Modelin Varsayımları}

Nordhaus'un politik konjonktürel dalgalanmalarla ilgili modeli çeşitli varsayımlara dayanmaktadır. Bu varsayımları Alesina, Cohen ve Roubini (1991), Alesina ve Roubini (1992), ve Alesina, Cohen ve Roubini (1997) yaptıklan çalışmalarda yedi varsayım altında toplamışlardır. Bu modelin varsayımlannı şöyle sıralayabiliriz (Alesina ve diğerleri, 1997:17-21; Alesina, Roubini ve Cohen, 1991:s.3; Alesina ve Roubini; 1992;665). 
1.Ekonomi, bekleyişler eklenmiş Phillips eğrisi tarafından karakterize edilmiştir.

2.Modelin ikinci varsayımı enflasyon beklentilerinin uyarlayıcı (adaptive) olmasıdır. Nordhaus seçmenlerin bekleyişlerinin uyarlayıcı olduğunu kabul etmiş ve bunun sonucunda da kendilerini iktidann performansına göre uyarlamaktadırlar (Nordhaus, 1975:174).

3.Politikacılar birbirinin benzeridir; işbaşında olmayı muhalefette olmaya tercih ederler. Partiler arası politika farklılıkları dikkate alınmamaktadır. Modelin perspektifinden bakıldığında bu rasyonel davranıştır (Nordhaus, 1975:174). İktidar partisi yeniden seçilebilmek için iktidarının ilk yıllarında ekonomiyi daraltıcı, iktidarının ikinci bölümünde ise ekonomiyi genişletici politikalar izlerler. Bu tür davranışlar yeniden seçilme şanslanın arttırıcı niteliktedir.

Modelin varsayımlanına göre, partiler siyasi avantajla ilgilenmekte, ideoloji ile ilgilenmemektedir. Türkiye'de politik konjonktürel dalgalanmaların araştırılmasında bu tür partizan modellerin kullanılması mümkün değildir. Çünkü Türkiye modelin gereklerini tam karşılamamaktadır (Derin, 2002:21).

4. Her seçimde birbirinin rakibi iki parti vardır. İktidar ve muhalefet.

5- Seçmenler ekonomik büyümeyi severken, enflasyon ve işsizlikten hoşlanmazlar (Nordhaus, 1975:171-172).

6 - Toplam talebi etkileyen politika araçlan siyasi karar vericilerin kontrolünde bulunmaktadır. Yani bir politika aracı olan para ve maliye politikalan politikacılar tarafından kullanılmaktadır. İktidar partisi tarafından kullanılan bu politikaların etkin kullanıldığı kabul edilmektedir (Nordhaus, 1975;172). Bu şu anlama gelmektedir, seçmenler enflasyon ile işsizlik arasındaki ilişkiyi anlamamaktadır, bu nedenle de bugünün düşük işsizliği ile geleceğin yüksek enflasyonu arasında bağlantı kuramamaktadır. İkincisi, seçmenin beklentileri adaptiftir, yani bilgileri geçmiş deneyimlerine dayanmaktadır. Bekleyişlerine, geleceğe yönelik bilgilerini dahil etmemektedir. Çünkü geleceğe yönelik bilgilerin nasıl toplanacağını, yorumlanacağını veya bu bilgileri beklentilerine nasıl dahil edileceğini bilememektedirler (Derin, 2002:39).

7-Seçim zamanı exojenist değişken olarak kabul edilmektedir. Bu varsayım ABD için geçerli olmakla birlikte, bir çok ülke için mesela, OECD ülkeleri, Türkiye, Japonya vb. ülkeler için geçerli değildir. Çünkü bu ülkelerde seçim zamanı sabitlenmemiştir. Yasaların izin verdiği ölçülerde seçim dönemleri değişebilmektedir. 
Alesina, Cohen ve Roubini (1991), Alesina ve Roubini (1992), ve Alesina, Cohen ve Roubini (1997), Nordhaus modelinin sabit seçim dönemlerine dayandınldığını belirtmişlerdir. Fakat Derin (2002) yaptığı çalışmada, bu modelin böyle bir sınırlandırma ile uygulanmasının doğru olmayacağını ileri sürmektedir. Nordhaus' un çalışması yakından analiz edilince modelin açık olarak seçim dönemini endojen veya exzojen olarak belirtmediği görülmektedir. Çünkü yapmış olduğu ampirik çalışmada ele aldığı ülkeler arasında seçim dönemi egzojen olarak belirlenen ülkeler olduğu gibi, seçim dönemi endojen olarak belirlenen ülkelerde vardır. Nordhaus' un örneğinde kullandığı $\mathrm{ABD}$ ve İngiltere exzojen seçim tarihi kullanan ülkeler iken, Kanada, Avustralya, Fransa, Almanya ve Japonya endojen seçim dönemi kullanan ülkeler arasındadır.

Bu varsayımlar altında test edilebilir bazı sonuçlar şunlardır:

1- Her hükümet aynı politikalan takip eder;

2- Kısa dönem Phillips eğrisinin avantajlanın kullanabilmek için hükümetler iktidarlarının son dönemlerine doğru ekonomiyi manipüle ederler.

3- Seçim öncesi ekonomik genişleme nedeniyle enflasyon oranının arttığı, seçimlerden sonra tersi politikalar nedeniyle enflasyonun düştüğü görülür (Alesina, 1992).

\subsubsection{Modelin İşleyişi}
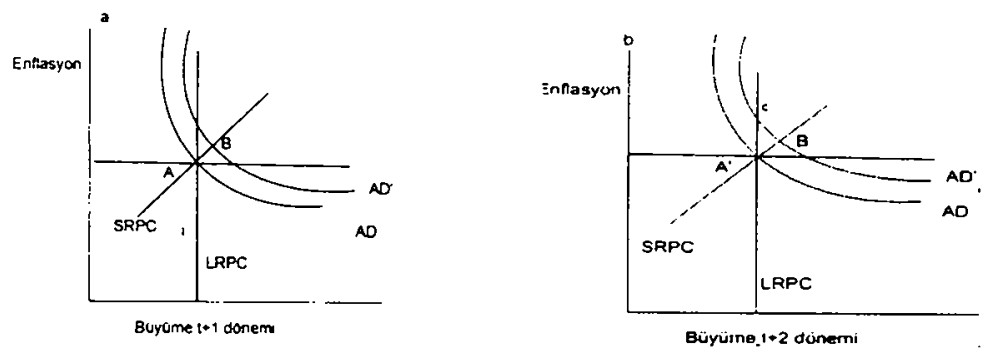

Şekil 1 Geleneksel Fırsatçı Modelin İşleyişi

LRPC Uzun Dönem Phillips Eğrisi

SRPC Kısa Dönem Phillips Eğrisi

AD Seçim Öncesi Toplam Talep Eğrisi

AD' Seçim Sonrası Toplam Talep Eğrisi 
Yukarıdaki şekil 1 geleneksel fırsatçı modelin nasıl çalıştığını göstermektedir. Şekilde $\quad \Pi_{\mathrm{t}}=\Pi_{\mathrm{t}}{ }^{\mathrm{e}}$ durumlar için uzun dönem Phillips eğrisi (LRPC), $\Pi_{t \neq} \Pi_{t-1=} \Pi_{1}{ }^{e}$ durumları içinde kısa dönem Phillips eğrisi (SRPC) yer almaktadır. A noktasını ele alalım. Burada kısa ve uzun dönem eğrileri kesişmektedir, bu durumda $\Pi_{t}=\Pi_{t \cdot l=} \Pi_{t}{ }^{\text {e }}$ olur. $t+1$ döneminin sonunda seçimlerin olduğunu farz edelim ve para ve maliye politikaları sonucu toplam talep eğrisi (AD) yer değiştirir. İktidarın para ve maliye politikalarını harekete geçirmesiyle, toplam talep genişler ve $t+1$ döneminde $B$ noktasına hareket edilir. B noktasında enflasyon beklenenden büyüktür, $\Pi_{t+1}>\Pi_{t}=\Pi_{t+1}{ }_{t+1}$. Böylece büyümede normalin üstünde gerçekleşir, yani, $y_{t+1}>\tilde{y}$. Böylece dönem sonunda yapılan seçimler normal üstü büyüme ve orta enflasyon artışının bulunduğu şartlarda gerçekleştirilir.

Yukarıdaki şartlarda gerçekleştirilen seçim sonucunda farz edelim ki iktidar partisi tekrar seçimleri kazansın (Çünkü B noktası ekonomik açıdan oldukça iyi bir noktadır). Şeklin ikinci kısmında görüldüğü gibi $t+2$ döneminde beklentiler normale dönecektir, çünkü $t+1$ döneminde bekleyişlerde hata vardır, yani $\Pi_{1+1}>\Pi^{e}{ }_{i+1}$ Eğer iktidardakiler toplam talebi daha fazla genişletmezlerse, ekonomi toplam talep eğrisi ile birlikte $C$ ( $A D^{\prime}$ ile LRPC'nin kesişimi) noktasına doğru hareket eder. $C$ noktasında büyüme doğal oranında, $\tilde{y}$, fakat enflasyon A noktasından daha yüksek bir düzeydedir. Politikacılar seçimlerden sonra eğer isterlerse, toplam talebi kısıcı politikalarla enflasyonu A noktasına geri getirebilirler. Bu tür politikalar durgunluğa yol açabilir. Fakat gelecek seçim dönemine kadar ekonomi A noktasına gelir ve seçim döneminde B noktasına hareket ettirilmeye hazır hale gelir. Nordhaus (1975) belli özel tercihler altında politikaciların ülke ekonomisini A noktasına getirmeyebileceğini, $A^{\prime}$ dan daha yüksek bir nokta olan $A^{\prime}$ noktasında bırakacağını belirtmiştir. Böylece şekil l' de gösterildiği gibi her seçim döngüsünde enflasyon oranının artığı gözlemlenebilir (Alesina, Roubini ve Cohen, 1997: 21-22).

\section{TÚRKIYE'DE ÇOK PARTILI DÖNEM}

Burada önemle üzerinde durulması gereken konu çok partili hayata geçiştir. Çünkü politik konjonktürel dalgalanmalan analizinin temel hareket noktası demokrasinin varlığıdır. Çok partili, serbest seçimlerin olmadığı ülkelerde bu tür hareketlerin varlığından bahsetmek mümkün değildir. Bu nedenle incelememize Türkiye'de çok partili hayata geçildikten sonraki dönem dahil edilecektir. Türk siyasal yaşamında çok partili dönem 1946 seçimleri ile başlamakla beraber bu seçimlerin tam bir politik rekabet içinde yapılmadığ ve seçimler üzerinde şaibeler olması nedeniyle (açık oy, gizli sayım esasının 
uygulanmas1, Demokrat partinin örgütlenmesini tamamlanmadan seçimlerin yapılması vs.) analizlere 1950 seçimleri ve sonrası dahil edilmiştir. 1950 seçimlerini \%53'lük oy oranıla CHP'ye (Cumhuriyet Halk Partisi) karşı DP (Demokrat Parti) kazanmıştır. Bundan sonra yapılan 1954 ve 1957 seçimlerini de kazanan DP parti 1960 askeri darbesi ile görevden uzaklaştırılmıştır. Daha sonra 1961 yılında yapılan seçimlerde hiçbir parti tek başına iktidara gelecek kadar oy alamadığından 1965 seçimlerine kadar 3 koalisyon hükümeti kurulmuştur. 1965 yılında yapılan seçimlerde AP oy oranını \% 52'ye çıkararak tek başına iktidara gelmiştir. Bunu takip eden 1969 seçimlerinde de AP tek başına iktidar olacak oy oranınıa ulaşmıştır. Fakat bu başarı çok uzun ömürlü olmamıs 12 Mart 1971 yılında ordunun verdiği bir muhtıra ile AP hükümeti görevden uzaklaştınImıştır. Bundan sonra 1973 yılında yapılan seçimlere kadar atanmış bir hükümet görev yapmıs ve bu seçimleri uzun yıllardan sonra CHP birinci parti olarak kazanmıştır. Fakat almıs olduğu \% 33 oy oranı tek başına iktidar olmasına yetmediği için MSP (Milli Selamet Partisi) ile koalisyon hükümeti kurmuştur. Bu koalisyon hükümeti 1974 yılında sona ermiş ve AP nin liderliğinde sağ partilerden oluşan koalisyon hükümeti 1977 seçimlerine kadar görev yapmıştır.

1977 seçimlerinde CHP \% 41,4 AP ise \% 36,9 oy alarak bir önceki seçime göre oylarını artırmı olmalarına rağmen, seçim sistemi nedeniyle hiç biri tek başına iktidara gelebilecek çoğunluğu elde edememiştir. ilk önce CHP azınlık hükümeti kurulmuş ve 1 ay görev yapabilmiştir. Daha sonra ise, AP, MHP ve MSP' nin oluşturduğu İkinci Milliyetçi Cephe hükümeti kurulmuş ve bu hükümet 1977 yılının sonuna kadar görevde kalmıştır (Varım, 1997:47). 1978 yılının başında CHP, CGP ve DP'nin desteğiyle hükümet kurmuş, fakat Ekim 1979'da yapılan ara seçimlerde bütün milletvekillerini AP'nin alması nedeniyle görevi bırakmışlardır. Bu defa AP, MHP'nin desteğiyle hükümeti kurmuş, fakat 12 Eylül 1980 darbesiyle demokrasi tekrar kesintiye uğramıştır (TUGİAD, 1986:34).

1980'den başlayıp 2003 yılı sonuna kadar geçen dönemi ise, yeniden demokrasiye geçiş çabalannın olduğu, Anavatan Partisi (ANAP), daha sonra Doğru Yol Partisi (DYP) ve Adalet ve Kalkınma Partisinin (AKP).iktidar yıllarıdır. Bu dönemde ilk demokratik seçimler 1983'te yapılmış ve Turgut Özal'ın önderliğindeki Anavatan Partisi (ANAP) seçimleri \% 45.2 oy alarak kazanmıştır. Bundan sonra Türk siyasal hayatında ANAP dönemi başlamış ve 1987 seçimlerinde de birinci parti olmuştur. 1991 yılında yapılan seçimlerde birinci parti genel başkanlığını Süleyman Demirel'in yaptığı Doğru Yol Partisi (DYP) olmuştur. Fakat DYP'nin aldığı \% 27 oy oranı tek başına iktidar olmasına yetmemiştir. DYP-SHP koalisyon hükümeti kurulmuştur (TUGIAD, 1986:37). Koalisyon hükümeti aralık 1995 seçimlerine kadar görevde kalmıştır. 
1995 seçimlerinde Refah Partisi (RP) \% 21.4'lük oy oranı ile en yüksek oyu almıştır. DYP ve ANAP ikinci ve üçüncủ sırada kalmıştır. Refah partisi birinci parti olmasına rağmen hükümeti kurmayı başaramadığından bu dönemde önce ANAP lideri Mesut Yılmaz'ın başkanlığnnda ANAP-DYP koalisyon hükümeti, daha sonra Refah-Doğru Yol koalisyon hükümeti ve ANAP-DSP-DTP koalisyon hükümeti bu döneme damgasını vurmuştur. Bu dönem 3 Kasım 1999'da sona ererken Bülent Ecevit başkanlığındaki azınlık hükümeti görev başında bulunmaktaydı. 1999 seçimlerini DSP \% 22 lik oy oranı ile birinci parti durumunda bitirmiş ve DSP-MHP-ANAP koalisyon hükümeti kurulmuştur. Bu dönemde Türkiye ekonomisi cumhuriyet tarihinin en büyük ekonomik krizini yaşamış ve 3 Kasım 2002 erken seçimler yapılmıştır. Bu seçim sonucunda sadece AKP ve CHP \% 10 seçim barajını geçen partiler olmuştur. AKP aldığı oy oranı ile tek başına iktidar partisi olmuştur.

\section{MODEL}

$\mathrm{Bu}$ çalışmada seçimleri kazanmak isteyen iktidar partilerinin makro ekonomik göstergeleri seçim dönemlerinde sistematik olarak manipüle edip, etmedikleri incelenecektir. Bu amaçla Alesina, Cohen ve Roubini (1991) tarafından OECD üyesi 18 ülkeyi kapsayan çalışmada benimsenen model kullanılmıştır. Geleneksel fırsatçı politik konjonktürel dalgalanmaların ölçülmesinde çoğunlukla bu modelin versiyonlan değişik çalışmalarda kullanılmıştır. Bu modelde ekonomik bekleyişler Phillips eğrisi tarafından karakterize edilmiştir ve enflasyon beklentileri uyarlayıcıdır. Politikacılar birbirlerinin benzerleridir. Birden çok partinin bulunduğu seçimlerde seçmenler ekonomik büyümeyi severken, işsizlikten ve enflasyondan hoşlanmazlar. Alesina, Cohen ve Roubini (1991) bu çalışmada hem politika çıktılarına göre hem de politika araçlanna göre analiz yapmıştır. Benzer bir model Treisman ve Gimpelson (2001) tarafından Rusya yı ele alan çalışmada kullanılmıştır. Modelin esası ekonomik değişkenin açıklanmasında seçimlerin etkili olup olmadığına bakılarak politik konjonktür dalgalanmalann varlığını tespit etmektir. Bu model şu şekilde özetlenebilir.

$$
Y_{t}=\alpha+\beta_{1} Y_{t-i}+\beta_{2} P B C+\varepsilon_{t}
$$

Burada Y ekonomik bir değişkendir, hem politika çıktılarını, hem de politika araçlarını temsil etmektedir. Ekonomik değişkenin açıklayıcısı olarak $\mathrm{Y}_{\mathrm{t}-\mathrm{i}}$ kullanılmıştır. Ve bu değişkenin açıklama niteliğine göre gecikme birden çok dönemi kapsamaktadır. PBC politik konjonktürel dalgalanmalanı varlığını ölçmek amacıyla kullanılan gölge değişkeni göstermektedir. Bu değişken analizin yıllık veya çeyrek dönemlik analiz olması durumuna göre seçim 
dönemlerinde 1 değerini alırken diğer dönemlerde 0 değerini almaktadır. $\varepsilon$ hata terimini göstermektedir.

Türkiye'deki politik konjonktürel dalgalanmaların varlığını ölçmek amacıyla kullanılan değişkenler ekonomik çıktılara ve ekonomik araçlara göre bir sınıflamaya tabi tutulacaktır. Ekonomik çıktı değişkenleri ekonomik büyüme ve enflasyondur. Politik konjonktürel dalgalanmaların varlığını enflasyon oranı ile test etmek önemlidir. Çünkü Türkiye'nin son 30 yıldır en önemli ekonomik problemi enflasyon olmuştur. Ayrica hükümetlerin KİT ürünlerinin fiyat artışlanın seçim sonrası döneme erteleyerek enflasyonda düşme olduğu izlenimini verme çabaları gözlenmektedir. Aynca işsizlik verileri çok uzun yıllara gitmediği gibi Türkiye için çok da güvenilir bir değişken değildir. İş arayan kişiler Îs ve İş̧i Bulma Kurumuna kayıt olmamaktadır. Çünkü son yıllara kadar işsiz kalınca ödenen bir işsizlik ödeneği olmadığı için, bu tür resmi kurumlara kayıt olmanın bir getirisi olmamaktadır. Bunun dışında Türkiye'de kayıt dışı çok fazla iş gücü çalıştınldığı da bilinen bir gerçektir. Bu nedenlerden dolay analizimize önemli bir politika çıktısı olan işsizlik değişkenini dahil etmedik.

Ekonomik araç değişkenleri ise kamu harcamalan, bütçe açığı, para arzı, faizler olarak ele alınmıştır. Bunun dışında birde politik konjonktürel dalgalanmaların sektörler üzerinde etkili olup olmadığı test edilmiştir. Bunun içinde eğitim, sağlık ve savunma harcamaları ile sanayi, ticaret ve tarım sektörlerindeki değişkenler ekonomik deģişken olarak analizde kullanılacak ve tahmin edilecektir.

\section{VERILER}

Çalışmada kullanılan veriler öncelikle IMF International Financial Statistics'lerin değişik sayılarından elde edilmiştir. Bunun yanında DİE ve DPT verileri gerekli olduğu durumlarda kullanılmışlardır. Bütün finanssal veriler gerektiğinde GSMH deflatörü kullanılarak sabit fiyatlara çevrilmiş ve bunlann artış oranları bulunmuştur. Tahminler artış oranları üzerinden yapılmıştır. Artıs oranlarının kullanılması büyük ölçüde birim kök sorununun oluşmamasını sağlamıştır. Seçimlerle ilgili veriler DIE seçim istatistiklerinden alınmıştır.

\section{TAHMINLER}

1950-2003 yıllannı kapsayan yıllık analizde kullanılan modeller ve kısaltmalar şu şekildedir. 


\begin{tabular}{|c|c|}
\hline$G S M H B U Y=\alpha+\sum \beta_{1} G S M H B U Y_{1-i}+\beta_{2} P B C D U M M+\varepsilon_{1}$ & $(2)$ \\
\hline$G S M H B U Y=\alpha+\sum \beta_{1} G S M H B U Y_{-i}+\beta_{2} Y A T I R+\beta_{3} P B C D U M M+\varepsilon_{t}$ & (3) \\
\hline$T U F E=\alpha+\sum \beta_{1} T U F E_{i-i}+\beta_{2} P B C D U M M+\varepsilon_{1}$ & (4) \\
\hline$K A H A R=\alpha+\sum \beta_{1} K A H A R_{t-i}+\beta_{2} P B C D U M M+\varepsilon_{t}$ & (5) \\
\hline$B U T A C I K=\alpha+\sum \beta_{1} B U T A C I K_{t-i}+\beta_{2} P B C D U M M+\varepsilon_{t}$ & (6) \\
\hline$M 1=\alpha+\sum \beta_{1} M 1_{t-i}+\beta_{2} P B C D U M M+\varepsilon_{t}$ & $(7)$ \\
\hline$V E R G I=\alpha+\sum \beta_{1} V E R G I_{t-i}+\beta_{2} P B C D U M M+\varepsilon_{t}$ & $(8)$ \\
\hline
\end{tabular}

GSMHBUY: Gayri safi milli hasıladaki yıllık artı̧ları göstermektedir. 19512003 yıllan arasındaki yıllık GSMH değerleri önce GSMH deflatörü kullanılarak 1987 sabit fiyatlanna çevrilmiş ve artış oranı hesaplanmıştır.

YATIR: Yatırımlardaki reel yüzde değişmeyi ifade etmektedir

TUFE: Seçimlerin enflasyon üzerindeki etkilerini ölçmek üzere tüketici fiyatlanı endeksindeki artışlar TUFE değişkeninin oluşturmuştur. (yıllık yüzde değişim oranı)

PBCDUMM: Politik konjonktürel dalgalanmaları ölçmek amacıyla kullanılan kukla değişkendir. Seçim yılları için 1 değerini alırken diğer yıllarda 0 değerini almaktadır.

KAHAR: Kamu harcamalarındaki artışları ölçen değişkendir. Cari değerler GSMH deflatörü aracılığıyla sabit fiyatlara çevrilmiş ve artış oranlan hesaplanmıştır

BUTACIK: Bütçe açıklannndaki değişmeleri gösteren değişkendir. Konsolide bütçe içinde yıllar itibariyle oluşan açıklar (fazlalar) sabit fiyatlara çevrilmiş ve artı̧ oranlan hesaplanmıştır.

M1: Para arzındaki artışlan ifade eden değişkendir. Yukarıdaki şekilde hesap edilmiştir (yıllık yüzde değişim oranı).

DUMM1980: Para arzı ile ilgili yapılan tahminde 1980 yılından sonrası için step kukla değişken kullanılmıştır. 1980 yılından sonra koklu parasal sistemlerdeki değişikleri absorbe etmesi için 1951-1980 yıllarına 0 değeri verilirken 1980-2003 yıllan 1 değerini almaktadır. 
VERGİ: Kamu gelirlerini temsilen 1950-2003 yılları arasındaki toplam vergi gelirler önce sabit fiyatlara çevrilmiş ve daha sonra artış oranları hesaplanmuştır.

Kullanılan değişkenler çoğunlukla artış oranı yada yıllık yüzde değişim şeklindedir. Bu tip verilerde birim kök sorunuyla genellikle karşılaşılmamaktadır. Buna rağmen birim kök sınamalan yapılmıs ve serilerin durağan olduğu görülmüştür.

\section{Analiz \\ 6.1. 1950-2003 Yıllık Politika Giktılanna Göre Genel} Tablo 1. 1953-2003 Ekonomik Büyüme ve Politik Konjonktürel dalgalanmalar İlişkisi

\begin{tabular}{|c|c|c|c|}
\hline & Katsayı & $\mathrm{t}$ istatistiğ $\mathrm{i}$ & t olasılığ \\
\hline Sabit & 5,194 & $4,715^{* * *}$ & 0,00 \\
\hline GSMHBUY_1 & $-0,105$ & $-0,785$ & 0,43 \\
\hline GSMHBUY_2 & 0,115 & 0,882 & 0,38 \\
\hline PBCDUMM & $-3,035$ & $-2,207 * *$ & 0,03 \\
\hline $\mathrm{R}^{2}$ & 0,121 & & \\
\hline$F(3,47)$ & $2,159^{*}$ & & \\
\hline AR 1-2F $(2,45)$ & 0,276 & & \\
\hline
\end{tabular}

Büyüme politik konjonktürel dalgalanmalan belirlemede kullanılan en önemli değişkendir ve tüm ekonomik değişkenlerin bütününü kapsamaktadır. Bu amaçla yapılan tahminde 1950-2003 yılları arasında ekonomik büyüme ve seçimler arasındaki ilişkinin varlığı ölçülmüştür. Sonuçlar böyle bir ilişkinin varlığını doğrulamaktadır. Ekonomik büyüme ve seçimler arasında negatif bir ilişki söz konusudur. Sonuç bu yönde çıkmakla birlikte, açıklayıcı gecikmeli büyüme değişkenlerindeki $t$ istatistiklerinin ve $r$ karenin düşük çıkması bu tahminin güvenilirliğini şüpheli hale getirmektedir. Bu nedenle gecikmeli açıklayıcı değişkenlerin yerine, büyümenin temel belirleyici olan yatırımlan kullanarak analizimizi tekrar yapma ihtiyacı doğmuştur. 
Tablo 1A. 1965-2003 Ekonomik Büyüme Politik Konjonktürel Dalgalanmalar İlişkisi

\begin{tabular}{|l|l|l|l|}
\hline & Katsayı & $t$ istatistiği & $t$ olasılı̆̆ \\
\hline Sabit & 4,202 & $7,148^{* * *}$ & 0,00 \\
\hline GSMHBUY_1 & $-0,297$ & $-3,310^{* * *}$ & 0,00 \\
\hline YATIR & 33,432 & $9,228^{* * *}$ & 0,00 \\
\hline PBCDUMM & $-1,594$ & $-1,747^{*}$ & 0,08 \\
\hline$R^{2}$ & 0,734 & & \\
\cline { 1 - 2 }$(3,35)$ & $32,263^{* * *}$ & & \\
\cline { 1 - 2 } AR $1-2 \mathrm{~F}(2,33)$ & 0,705 & & \\
\cline { 1 - 2 } & & &
\end{tabular}

Tablo 1A da ekonomik büyümenin geçmiş yll ekonomik büyümesi, yatınımlar ve seçimler tarafından belirlendiği varsayımı altında ikinci regresyon analizi görülmektedir. Bu analizde $r$ kare yeterince yüksek ve $t$ istatistikleri de böyle bir tahmin için tatmin edici değerleri almıştır. Seçimler ile büyüme arasındaki negatif yönlü ilişki bu tahminde de geçerlidir. 1950-2003 dönemi dikkate alınarak Türkiye'de ekonomik büyüme seçimlerden negatif yönde etkilenmektedir sonucuna varmak mümkün görünmektedir. Seçimlerin büyüme üzerindeki olumsuz etkisi sistematik ve güçlü bir etkidir. Yani Türkiye'de seçimlerin olduğu yıl ekonomik büyüme negatif yönde etkilenmektedir.

Tablo 2. 1953-2003 Fiyatlar (TUFE) Politik Konjonktürel Dalgalanmalar İlişkisi

\begin{tabular}{|l|l|l|l|}
\hline & Katsayı & $t$ istatistiği & t olasılığ \\
\hline Sabit & 5,615 & $1,710^{*}$ & 0,09 \\
\hline TUFE_1 & 0,897 & $6,090^{* * *}$ & 0,00 \\
\hline TUFE_2 & $-0,009$ & $-0,065$ & 0,94 \\
\hline PBCDUMM & $-4,453$ & $-0,981$ & 0,33 \\
\hline$R^{2}$ & 0,811 & & \\
\cline { 1 - 1 } F $(3,47)$ & $67,345^{* * *}$ & & \\
\cline { 1 - 2 } AR 1-2F $(2,45)$ & 1,226 & & \\
\cline { 1 - 2 } & & &
\end{tabular}


Yıllık data ile politika çıktılarına göre analizimizde son yapılan tahmin fiyatlar genel düzeyinin diğer deyişle enflasyon ile seçimler ilişkisidir. Hükümetlerin seçim öncesi genişletici politikalar uygularken seçim sonrası daraltıcı politikalar izleyerek enflasyonu düşürme yönüne gitmeleri şeklindedir. Böyle bir ilişkinin Türkiye için de beklenmesine rağmen regresyon sonuçlan bu ilişkinin varlığına ilişkin herhangi bir işaret göstermemektedir. Seçimleri gösteren PBCDUMM değişkeni istatistiki olarak anlamlı değildir. Buradan anlamlı bir ilişkinin çıkmaması, enflasyon sürecinin yapısından kaynaklanmıs olabilir. Türkiye'de yaşanan çok uzun süreli, kronik enflasyon problemi, hükümetin seçim sonrası enflasyonu düşürme çabalarını sınırlandıran bir etken olabilir. Bunun dişında enflasyonun seçim sonrası dönemierde düşürülememesi hükümetlerin ekonomiyi tam anlamula kontrol edemedikleri anlamina da gelebilir. Buda Türkiye gibi gelişmekte olan ülkelerde hükümetlerin enflasyon, işsizlik gibi politika çıktılanını tam anlamıyla kontrol edemediklerini göstermektedir. Aynca Türkiye'nin çok uzun yıllar çok yüksek oranlarda enflasyon oranı ve ekonomik krizlerle yaşaması nedeniyle, modelimiz enflasyondaki seçimler nedeniyle oluşacak değişiklikleri gözlemlemede yetersiz kalıyor olabilir. Enflasyonun daha dengeli dalgalanmalar gösteren gelişmiş ülkelerde bu değişkenin politik konjonktürü ölçmede daha etkili olabileceği düşünülmektedir.

\subsection{0-2003 Yullik Politika Araçarina Göre Genel Analiz}

Politik konjonktürel dalgalanmalann varlığı politika araçlanna göre de test edilebileceğinden, bu bölümde politika aracı olan kamu harcamaları, para arzı, vergiler, bütçe açıklarının 1950-2003 dönemi itibariyle seçimlerden nasıl etkilendiği test edilecektir.

Tablo 3. 1953-2003 Kamu Harcamaları Politik Konjonktür İlişkisi

\begin{tabular}{|l|l|l|l|}
\hline & Katsayı & t istatistiği & t olasılığı \\
\hline Sabit & $-0,380$ & $-0,278$ & 0,99 \\
\hline KAHAR_1 & 0,919 & $6,590^{* * *}$ & 0,00 \\
\hline PBCDUMM & 2,627 & $2,830^{* * *}$ & 0,00 \\
\hline$R^{2}$ & 0,863 & & \\
\cline { 1 - 1 } F $(3,47)$ & $99,398^{* * *}$ & & \\
\cline { 1 - 1 } AR 1-2F $(2,45)$ & 1,325 & & \\
\cline { 1 - 2 } & &
\end{tabular}


Analizimize ekonominin tümü yerine sadece kamu harcamalarının seçimlerden nasıl etkilendiği yönünde geliştirirsek, Tablo 3 deki sonuçlara ulaşınz. Kamu harcamaları ile seçimler arasında güçlü pozitif ilişki söz konusudur. Hükümetler seçim dönemlerinde kamu harcamalarını hızla artınp, iktidar güçlerini oylarını maksimize etme yönünde kullandıklarını gösteren bir sonuç ortaya çıkmaktadır. Kamu harcamalarının artışı ile ekonomik büyümenin negatif ilişkisini bir arada düşündüğümüzde. Hükümetin kamu harcamaları artışı, özel harcamaları dışlayıcı etki gösterdiği bu nedenle büyümeye negatif etki ettiği sonucuna vanlabilir. Seçim yıllarında kamu harcamalannın artması, büyümenin ise negatif olması aslında düşündürücü bir sonuçtur. Fırsatçı konjonktürel dalgalanmalar teorisine göre seçim yılında ve seçimlerden hemen önceki dönemde ekonomik büyümenin var olması gerekir. Oysa Türkiye'de bu durum tersinedir. Bu bize Türkiye'de hükümetlerin ekonomiyi tam anlamyla kontrol edemediklerini göstermektedir. Ayrıca seçim yıllarında özel sektöründe bir bekleyiş içine girip, yatınm yapmadığını işlerin bu yıllarda yavaş yürüdüğünü düşünebiliriz.

Tablo 4. 1953-2003 Konsolide Bütçe Açı̆̆ı Politik Konjonktür İlişkisi

\begin{tabular}{|l|l|l|l|}
\hline & Katsayı & t istatistiği & t olasılığı \\
\hline Sabit & 0,031 & 0,098 & 0,92 \\
\hline BUTACIK_1 & 0,664 & $4,885^{* * *}$ & 0,00 \\
\hline BUTACIK_2 & 0,336 & $2,234^{* *}$ & 0,03 \\
\hline PBCDUMM & $-1,407$ & $-2,675^{* *}$ & 0,01 \\
\hline$R^{2}$ & 0,851 & & \\
\cline { 1 - 2 } F $(3,48)$ & $85,517^{* * *}$ & & \\
\cline { 1 - 2 } AR 1-2F $(2,45)$ & 4,480 & &
\end{tabular}

İktidardaki hükümetin kamu harcamalannı artırarak seçimlerden avantajlı çıkma uğraşısını önceki tahminde destekleyen bulgular elde etmiştik. Tablo 4 teki tahminde ise seçim dönemlerinde bütçe açığının nasıl etkilendiği test edilecektir. Bütçe açığı ile seçimler arasında negatif yönlü ilişki beklenmektedir. Çünkü iktidardaki hükümetler kamu harcamalarını artırırken bunun vergilerle hemen finansmanı yoluna gitmeyi istemeyeceklerdir. Vergilerdeki artışlar seçmenlerin tercih ettiği bir durum değildir. Bu nedenle bütçe açığının konjonktürel politik dalgalanma söz konusuysa artması 
beklenmelidir. 1950-2003 yıllarını kapsayan yıllık verilerle yaptığımız tahmin beklentiler yönündedir. Seçimler ile bütçe açığı arasında negatif ilişki söz konusudur ve bu ilişki istatistiki olarak anlamlıdır. Yıllık verilerle yapılan şu ana ki kadar tahminler Türkiye'de politik konjonktürel dalgalanmalan doğrular niteliktedir.

Tablo 5. 1953-2003 Para Arzı Politik Konjonktür lliş̧kisi

\begin{tabular}{|l|l|l|l|}
\hline & Katsayı & t istatistiği & t olasılığ \\
\hline Sabit & 0,996 & $2,025^{* *}$ & 0,04 \\
\hline Ml_1 & 0,298 & $2,028^{* *}$ & 0,04 \\
\hline M1_2 & 0,272 & $1,828^{*}$ & 0,07 \\
\hline PBCDUMM & 0,141 & 0,264 & 0,79 \\
\hline DUMM1980 & 1,436 & $1,759^{*}$ & 0,08 \\
\hline$R^{2}$ & 0,611 & & \\
\cline { 1 - 1 } F (3, 48) & $18,078^{* * *}$ & & \\
\cline { 1 - 1 } AR 1-2F $(2,44)$ & 0,620 & &
\end{tabular}

Para arzı politik konjonktürel dalgalanmalar konusunda dikkat edilmesi gereken politika araçlarından bir tanesidir. İktidardaki hükümetler özellikle kamu harcamalarını artınrken bunun en kolay aracı olarak Merkez Bankasını kullanmak isterler. Para arzında seçim öncesi dönemde meydana gelecek artışlar halkın refah düzeyini artırdığı hissine neden olacak ve bu durumda oy maksimizasyonunu sağlayacaktır. Para arzı seçimler arasındaki bu yönde pozitif bir ilişki beklemekle birlikte bu yönde bir regresyon sonucu elde edilememiştir (Tablo 5). 1980 yılında parasal sistemde meydana gelen büyük değişiklikleri absorbe etmesi amacıyla 1980 yılından itibaren step dummy değişken kullanılmış yine bu durumda da PBCDUMM değişkeni yani seçimler ile para arzı arasında bir ilişki görülmemiştir. Politik konjonktürel dalgalanmalar diğer tahminlerde desteklenirken para arzı konusunda aynı sonuç gözlenmemiştir. Bu durum, Türkiye'de Merkez Bankası kaynaklarını iktidarların rahatça kullandığı savını çürütmektedir. Burada Derin (2002) yaptığı çalışma ile bir uyum görülmektedir. Derin'de TCMB aktif olarak politik konjonktürel dalgalanmaların sebebi olmadığını vurgulamıştır. 
Tablo 6. 1953-2003 Vergi Gelirleri Politik Konjonktür Illişkisi

\begin{tabular}{|l|l|l|l|}
\hline & Katsayı & t istatistiği & t olasilığı \\
\hline Sabit & 1,387 & 0,807 & 0,42 \\
\hline VERGI_1 & 0,721 & $5,069^{* * *}$ & 0,00 \\
\hline VERGí_2 & 0,201 & 1,315 & 0,19 \\
\hline PBCDUMM & 0,596 & 0,764 & 0,44 \\
\cline { 1 - 2 } $\mathrm{R}^{2}$ & 0,684 & & \\
\cline { 1 - 2 } F $(3,47)$ & $33,95^{* * *}$ & & \\
\cline { 1 - 2 } AR 1-2F $(2,45)$ & 0,147 & &
\end{tabular}

İktidarlann iktidar gücünü kullandıklan en önemli araçlardan bir diğeri de vergilerdir. Kamusal ihtiyaçlanın karşılanmasında finansman kaynağının tartışmasız en önemlisi ve en büyüğü vergilerdir. Vergiler seçmenlerin ödemeyi çok sevmedikleri bir olgudur. Bu nedenle hükümetler seçim öncesinde vergilerle hiç oynamamakta yada vergi indirimlerine gitmektedirler ve seçim sonralarında, artan bütçe açığını kapatmak üzere vergi artırımına gitmektedirler. $\mathrm{Bu}$ bilgiler sşığında bu regresyon tahmininde beklenen sonuç vergiler ile seçimler arasında negatif bir ilişkinin varhı̆ının olmasıdır. Yapılan tahminler neticesinde vergiler ile seçimler arasında sistematik bir ilişkiyi destekleyen sonuçlar görülmemiştir (Tablo 6). Vergiler seçimlerden bağımsız bir değişken olarak ortaya çıkmıştır. Bu durum vergi artırım yada indirimlerinin etkilerinin hemen görülmemesi, belli bir gecikmeyle ortaya çıkması nedeniyle tahminlerde yakalanmamıs olmasıyla açıklanabilir. Vergiler politikacıların hemen kullanabilecekleri, çabuk reaksiyon veren değişkenlerden değildir.

\section{SONUÇ}

Politik konjonktürel dalgalanmalar teorisi, geniş anlamıla kamu politikalannın oluşturulmasında siyasal etkilerin varlığına işaret etmektedir. Literatürde geleneksel fırsatçı konjonktürel dalgalanmalar modeli çok fazla çalışılmış ve orijinal halinden farklı şekillerde de yorumlanmıştır. Politik konjonktürel dalgalanmalarla ilgili yapılan ampirik çalışmalara bakıldığından çoğunluğunun $A B D$ ve gelişmiş batı ülkeleriyle ilgili olduklan görülür. Gelişmekte olan ülkelerle ilgili yapılan çalışmalar oldukça azdır. Bu nedenle bu çalışmada Türkiye'deki politik konjonktürel dalgalamaların var olup olmadığ1 ele alınmıştır. Bu amaçla yapılan ampirik çalışma önce politika çıktılarına 
(enflasyon ve büyüme), daha sonra ise politika araçlarına (M1, bütçe açıklan, kamu harcamaları, vergi gelirleri) göre analiz yapılmıştır. 1950-2003 dönemini kapsayan analizde ekonomik büyümenin seçimlerden olumsuz etkilendiği tespit edilmiştir. Yine aynı şekilde bu dönemler arasında bütçe açıklanının ve kamu harcamalarının seçimler dolayısı ile arttığı tespit edilmiştir. Kamu harcamalarının seçim dönemlerinde artmış olmasına rağmen, ekonomik büyümenin gerçekleşmemesi düşündürücüdür. Bu durum bize kamunun yapmış olduğu harcamalann genellikle transfer harcamaları şeklinde olduğunu göstermektedir. Siyasi partiler seçim dönemlerinde oylanını maksimize etmek amaciyla kamu harcamalarını hızla artırmakta ve bütçe açıklarının genişlemesine yol açmaktadır. Seçimlerin sıklıkla olması da ekonomik krizlere yol açmaktadır. Bütçe açıkları ile ilgili bulgu son yıllarda azalma göstermektedir. Bu da kurumsallaşmamın siyasi partilerin seçim nedeniyle manipülasyon yapma gücünü azalttığına işaret etmektedir.

Bu çalışmanın ortaya çıkardığı temel sonuç, Türkiye'de siyasi partiler oylarını maksimize etmek amacıyla ekonomiyi manipüle etmektedir, fakat bu etki çok büyük değildir ve son ylllarda giderek azalmaktadır.

Türkiye'de demokrasi ve çok partili seçim döneminin kısalığı, verilerin yetersizliği nedeniyle sonuçlar ihtiyatla değerlendirilmelidir. Bu çalışma sadece yıllık datalar ile yapılan tahminlerden oluşmaktadır ve bir yıl uzun bir süredir. Daha kısa süreli değişkenler kullanılarak yapılacak analiz, politik konjonktür hakkında bize daha fazla bilgi sunabilecektir. Gelecekte yapılacak çalışmalarda çeyrek dönemlik veriler kullanılması bize daha aynntılı bilgiler verecektir. Aynca bu çalışmada sadece genel seçimler dikkate alınmıştır. Gelecekteki çalışmaların mahalli idareler seçimlerini de dikkate alarak geliştirilmesi, ve benzer demokrasi deneyimine sahip ülkelerle karşılaştırılması da yararlı olacaktır.

\section{Kaynakça}

AKÇORAOĞLU, Alpaslan / YURDAKUL, Funda (2004), "Siyasal Ekonomi Açısından Büyüme, Enflasyon ve Bütçe Açıklan: Türkiye Üzerine Bir Uygulama," Siyasal Bilgiler Fakültesi Dergisi, 59/1: 1-25.

AKŞiN, Şina (2000), Türkiye Torihi 4: Çă̆daş Türkiye 1908-1980 (istanbul: Cem Yayınevi, Altıncı basim) .

ALCOE, Glen (2001), "Economic Theories of Voting and the Political Business Cycle: A CrossNational Comparative Analysis," Essex Üniversitesi Yayılanmamış Doktora Tezi.

ALESINA, Alberto / ROUBINI, Nouriel / COHEN, Gerald (1991), "Macroeconomic Policy and Elections in OECD Democracies," NBER Working Paper Series: 3830.

ALESINA, Alberto (1992), "Political Models of Macroeconomic Policy and Fiscal Reforms," The World Bank Working Papers (WPS 970). 
ALESINA, Alberto / Nouriel, Nouriel (1992), "Political Cycles in OECD Economies," Review of Economic Studies, 59: 663-688.

ALESINA, Alberto / ROUBINI, Nouriel / COHEN, Gerald (1997), Political Cycles and the Macroeconomy, (Cambridge: ABD, MIT Press).

AN, Yong Heun (2002), "Election, Electoral Pressure and Macroeconomic Policy: The Political Economy of Elections in Korea and Taiwan," California Üniversitesi Yayınlanmamış Doktora Tezi.

Cumhuriyeti Ansiklopedisi (2003), (istanbul: Yapı Kredi Yayınları, Dördüncü basım)

DERIN, Ibrahim (2002), "Do Political Business Cycles Exist in Turkey?," Claremont Graduate Üniversitesi Yayınlanmamış Doktora Tezi.

EROĞLU, Nadir (2003 "Türkiye'de Iiktisat Politikalannın Gelişimi," Marmara Üniversitesi Atatürk ilkeleri ve Inkilap Tarihi Araștırma ve Uygulama Merkezi'nin düzenlediği 80 . yilında Türkiye Cumhuriyeti Sempozyumunda sunulan bildiri (istanbul).

IMF, International Finance Statistics Yearbook (Washington) (Çeşitli Yillar).

KUZU, Yasemin (2001), "Türkiye Ekonomisinde Politik Devresel Hareketler," Ankara Üniversitesi Sosyal Bilimler Enstitüsü Yayınlanmamış Yüksek Lisan Tezi.

KUZU, Yasemin, "Political Business Cycle in the Turkish Economy: 1977-2001," www.econturk.org (erişim tarihi, 0cak 2005).

MAC RAE, Duncan (1977), "A Political Model of the Business Cycle," The Journal of Political Economy, 85/2: 239-263.

NORDHAUS, William D. (1975), "The Political Business Cycle," The Review of Economic Studies, 42/2: 169-190.

ONUR, Sara (....), "Politik Bütçe Döngüleri Bağlamında iç ve Dış Borçlanmanın Devlet Bütçesi Üzerindeki Etkisi," Ekonomi ve Toplum, 5/2 www.isgüc.org.

ONUR, Sara (2002) "Politik Bütçe Döngüleri ve Türkiye Ekonomisi (1975-2000)," Uludağ Üniversitesi, I.I.B.F Dergisi, 11/ 2: 85-126.

ONUR, Sara (2003), "Literatürde Ekonomi Politika ilişkisi," "/ş, Gü̧̧" Endüstri llişkileri ve Insan Kaynaklori Dergisi, 6/1 www. isgüic.org.

PALDAM, Martin (1979), "Is There An Election Cycle? A Comparative Study of Natioanal Accounts," Scandinavian Journal of Economics, 81: 323-342.

PALDAM, Martin (1983), "Industrial Conflicts and Economic Condition- A Comparative Emperical investigation," European Economic Review, 20: 231-256.

SAYAN, Serdar / BERUMENT, Hakan (1997), "Türkiye'de Siyaset Ekonomik Popülizm ve Hükümetler," Hacettepe Üniversitesi, III.B.F Dergisi, 15/ 2: 171-185.

TELATAR, Funda (2000), "Parlamenter Sistemlerde Politik Devresel Dalgalanmalar: Teori ve Türkiye Için Bir Uygulama," Gazi Üniversitesi Iktisadi ve ldari Bilimler Fakültesi Dergisi, 4: 133-154.

TELATAR, Funda (2004), Politik Iktisat Politikası (Ankara: Imaj Yayınevi).

TUGIAD (1986), 2000'li Yıllara Doğru Türkiye'nin Önde Gelen Sorunlarına Yaklaşımlar: Seçim Sistemi, Seri no: 18.

TREISMAN, Daniel / GIMPELSON, Vlademir (2001), "Political Business Cycless and Russian Elections or the Manipulations of "chudar," British Journal of Political Science, 31: 225.46.

VARIM, Suphi (1997) 2000'li Yıllara Doğru Türkiye'nin Önde Gelen Sorunlanına Yaklaşımlar: Seçim Ekonomisi (Türkiye Genç Iş̧adamlanı Derneği Yayınlan). 